\title{
Curse or Blessing? Natural Resources and Human Development
}

\author{
José Pineda and Francisco Rodríguez ${ }^{1}$
}

Human Development Report Office

\begin{abstract}
This paper argues against a natural resource curse for human development. We find evidence that changes in human development from 1970 to 2005, proxied by changes in the Human Development Index, are positively and significantly correlated with natural resource abundance. While our results are consistent with those of other authors who have recently argued that natural resources do not adversely affect growth, we find strong evidence that natural resources have a positive effect on human development and particularly on its non-income dimensions. However, results from Latin America interactions show that the positive impact of natural resources in this region is significantly smaller than in the rest of the world. These results contribute to a broader discussion about the "resource curse" by showing that natural resources may be a blessing rather than a curse for human development, primarily through its effects on education and health rather than income.
\end{abstract}

\footnotetext{
${ }^{1}$ This paper has benefited from previous discussions with Daniel Lederman, Ricardo Hausmann, Jeni Klugman, Jose Antonio Ocampo and Jaime Ros, as well as seminar participants at HDRO. We are grateful to Daniel Lederman and Bill Maloney for kindly providing us access to their data. The paper also benefited from excellent research assistance provided by Zachary Gidwitz, Martin Philipp Heger and Mark Purser. All errors remain our responsibility.
} 


\section{Table of Contents}

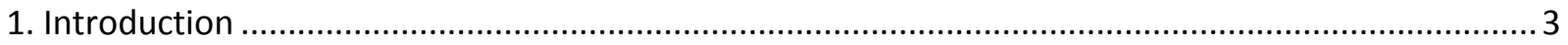

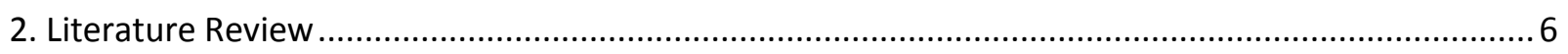

2.1 Latin America: a Regional Comparison ......................................................................... 12

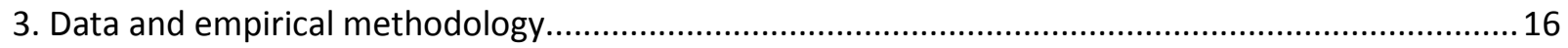

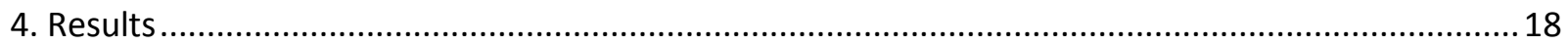

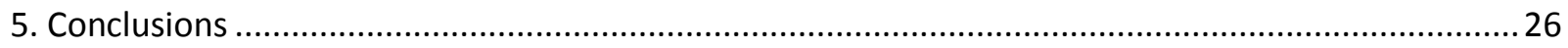

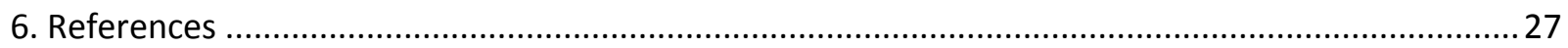

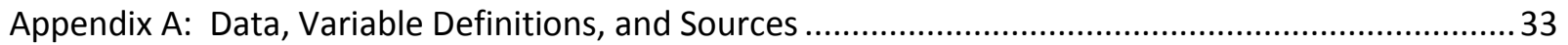




\section{Introduction}

It is paradoxical to think that natural resource riches hurt rather than help an endowed country. Yet this is precisely the argument that has permeated academic and policy circles for decades. A plethora of papers containing empirical analyses, game theoretic models, and case studies has appeared, attempting to explain why natural resources could be bad for economic growth and development. Some of the more popular explanations involve the Dutch Disease, economic volatility, rent-seeking, and weak institutions, all of which are argued to negatively impact growth.

However, with new empirical evidence and deeper probing into the causes of growth collapse, doubt has begun to build regarding a causal relationship between natural resources and economic growth. A growing literature has arisen involving those who do not subscribe to the theory of a natural resource curse or who believe in a conditional curse. Many success stories have arisen from natural resource wealth. Norway has long utilized its Petroleum Fund to stabilize its oil wealth, providing economic security for the country. More recently, Chile's Copper Stabilization Fund has proven to be a successful element in the country's economic recovery since the mid 1980s. In both cases, resource dependence presented challenges that were properly managed, resulting in economic prosperity. Key challenges in the literature involve disentangling the effect of natural resources from those of other factors which may be correlated with resource abundance but independently affect growth, distinguishing between the direct role that natural resources may play in affecting progress and the way in which it may interact with other determinants, and identifying exogenous sources of variation in resource abundance.

Recent studies have highlighted major differences between performance as measured by the yardstick of economic growth and human development. ${ }^{2}$ In particular, there is no significant correlation between per capita income growth and changes in the non-income components of human development, even over relatively long periods of time (up to four decades). While growth was stagnant for the poorest regions like Africa, adult literacy more than doubled and enrolment rates increased by 72 percent over the same period. If countries' performance in

\footnotetext{
${ }^{2}$ See Rodríguez(2009), Binder and Georgiadis (2010) and Gray and Purser (2009). Some of these points were raised earlier by Easterly(1999)
} 
growth and human development can be so disparate, one might also expect there to be differences in their correlates.

Building on the empirical and theoretical work done by Daniel Lederman and William F. Maloney (2008), this paper argues against a natural resource curse not only with respect to GDP growth but most importantly for other dimensions of human development. We show that changes of human development from 1970 to 2005, proxied by changes in the Human Development Index, are positively and significantly correlated with natural resource abundance. While our results are consistent with those of Lederman and Maloney, who find natural resources to be possibly positive for growth, we find strong evidence that natural resources are even better for the human development. This is particularly true for the non-income elements of human development.

This article also takes a close look at the Latin American case. Resource abundance has often been singled out as one of the culprits for the region's poor development. On the other hand, as we will discuss in the next section, there are quite a few cases in which resources have coexisted with strong performance in the region. Are natural resources harming Latin America's development prospects? Anticipating our results, we find evidence that the human development - enhancing effect of natural resources is lower in Latin America than in the rest of the world, suggesting that Latin America may not be fully taking advantage of the possibilities deriving from its factor endowments.

In Tables 1a-b, we present selected summary statistics of the main data we use in this paper, subdivided by countries that are net exporters and net importers of natural resources. ${ }^{3}$ Table 1a shows that compared with all countries, net importers have higher levels in HDI as well as in all of its components. However, looking at changes in variables reveals a somewhat different scenario. Changes in life expectancy are roughly the same across all country groupings. GDP growth has been smaller for net exporter countries, which is at the heart of the natural curse hypothesis. However, changes in the non-income component of HDI, primarily associated with literacy and gross enrolment, are on average larger for net exporting countries. Results are even stronger, in the comparison of changes, if we focus on the high net exporters and high net

\footnotetext{
${ }^{3}$ These are countries that export (import) more than the average.
} 
importers. As we can see from Table 1.b, all changes are greater for net exporters than net importers except for per capita GDP growth. This potentially indicates that natural resources affect human development primarily through channels other than income.

Table 1a. Summary Statistics: Mean of variables (All countries 1980-2005)

\begin{tabular}{lrrrrrrrr}
\hline & \multicolumn{3}{c}{ Levels } & & \multicolumn{3}{c}{ Changes } \\
\cline { 2 - 3 } \cline { 7 - 8 } & All countries & Net Exporters & Net Importers & & All countries & Net Exporter & Net Importer \\
\hline HDI & 0.7337 & 0.7102 & 0.7685 & & 0.0045 & 0.0043 & 0.0047 \\
non-income HDI & 108 & 57 & 51 & & 108 & 57 & 51 \\
& 0.7594 & 0.7321 & 0.7899 & & 0.0054 & 0.0056 & 0.0052 \\
GDP/capita & 110 & 58 & 52 & & 110 & 58 & 52 \\
& 8.67 & 8.5141 & 8.8282 & & 0.0153 & 0.0097 & 0.021 \\
Life Expectancy & 141 & 71 & 70 & & 141 & 71 & 70 \\
Gross Enrolment & 67.9206 & 65.5284 & 70.3446 & & 0.3059 & 0.3033 & 0.3085 \\
& 151 & 76 & 75 & & 151 & 76 & 75 \\
Literacy & 0.7143 & 0.6935 & 0.7377 & & 0.0066 & 0.007 & 0.0063 \\
& 115 & 61 & 54 & & 115 & 61 & 54 \\
& 0.8269 & 0.8142 & 0.8397 & & 0.0062 & 0.0068 & 0.0057 \\
& 140 & 70 & 70 & & 140 & 70 & 70 \\
\hline
\end{tabular}

Source: Own calculations

Table 1b. Summary Statistics: Mean of variables (High net exporters/importers 1980-2005)

\begin{tabular}{|c|c|c|c|c|c|c|}
\hline & \multicolumn{3}{|c|}{ Levels } & \multicolumn{3}{|c|}{ Changes } \\
\hline & All countries & High Net Exporters & High Net Importers & All countries & High Net Exporters & High Net Importers \\
\hline \multirow[t]{2}{*}{ HDI } & 0.7337 & 0.8371 & 0.8869 & 0.0045 & 0.0043 & 0.0042 \\
\hline & 108 & 29 & 25 & 108 & 29 & 25 \\
\hline \multirow[t]{2}{*}{ non-income HDI } & 0.7594 & 0.844 & 0.8904 & 0.0054 & 0.0055 & 0.0042 \\
\hline & 110 & 29 & 25 & 110 & 29 & 25 \\
\hline \multirow[t]{2}{*}{ GDP/capita } & 8.67 & 9.427 & 9.6968 & 0.0153 & 0.0107 & 0.0254 \\
\hline & 141 & 37 & 35 & 141 & 37 & 35 \\
\hline \multirow[t]{2}{*}{ Life Expectancy } & 67.9206 & 72.4482 & 75.4347 & 0.3059 & 0.3203 & 0.2858 \\
\hline & 151 & 38 & 38 & 151 & 38 & 38 \\
\hline \multirow[t]{2}{*}{ Gross Enrolment } & 0.7143 & 0.8045 & 0.8379 & 0.0066 & 0.007 & 0.0059 \\
\hline & 115 & 30 & 26 & 115 & 30 & 26 \\
\hline \multirow[t]{2}{*}{ Literacy } & 0.8269 & 0.8992 & 0.948 & 0.0062 & 0.0059 & 0.0035 \\
\hline & 140 & 36 & 34 & 140 & 36 & 34 \\
\hline
\end{tabular}

Note: High Net Exporters/Importers refer s to countries that are exporting/importing more than the average.

Source: Own calculations 
The remainder of the paper is organized as follows. Section 2 presents a literature review of the effect of natural resources on development: the theoretical arguments, different channels of impact, and why natural resources might not be a curse after all. Section 2 contains a special discussion that focuses on a comparative analysis of different growth experiences of Latin America and the rest of the world with respect to natural resources. Section 3 presents our data and empirical methodology. Section 4 discusses our results, which find natural resources to be positively correlated with human development. Section 5 concludes.

\section{Literature Review}

Broadly speaking, the resource curse literature has highlighted five channels through which growth may affect human development: Dutch Disease, volatility, trade structure, depletion, and rent-seeking, all of which are complicated by institutional weakness. We discuss each of these in turn.

The term 'Dutch Disease' was initially coined to describe the observed collapse of the Dutch manufacturing sector following the discovery of natural gas in $1959 .{ }^{4}$ Corden (1984) first modelled this effect. His basic model shows how capital moves away from non-oil tradables as oil booms, weakening the overall economy. An influx of foreign capital to the booming resource sector causes an appreciation in the exchange rate. A higher exchange rate raises economy-wide prices, leading the non-resource tradable sectors to lose competitiveness abroad.

Sachs and Warner (1995)'s empirical work brought this issue to the front line of the development debate. They showed that countries with a high ratio of natural resources to GDP in their base year, 1970, grew more slowly over the next two decades than their resource-scarce counterparts. Their analysis is cross-sectional, using the share of GNP in 1970 consisting of primary products to define natural resource abundance, and controlling for other potential growth determinants such as economic openness, rule of law and growth of external terms of trade and found a robust negative relationship between natural resources and growth.

\footnotetext{
4 “The Dutch Disease" (November 26, 1977). The Economist, pp. 82-83
} 
Humphreys, Sachs, and Stiglitz (2007) describe a related challenge of natural resource abundance and dependence: volatility. They view natural resources as assets with exceptional volatility. ${ }^{5}$ World natural resource prices are historically volatile due to varying rates of extraction, and the nature of contracts with multi-national companies. Stiglitz $(2007)^{6}$ and Shaxson (2005) argue that the latter effect arises from multinationals coercing countries into bearing the brunt of the income variability. Volatility has many adverse effects, including making development planning difficult, social spending sporadic, and foreign investors wary.

The problems of volatility are exacerbated when an economy is overly dependent on the natural resource industry. Lederman and Maloney $(2007)^{7}$ argue that a trade structure lacking export diversification hurts growth, not natural resources. To test this theory, they redo the Sachs and Warner analysis with the inclusion of variables for export concentration and intra-industry trade. Their findings demonstrate that any negative effect of natural resources on growth disappears in the presence of a variable capturing export concentration.

Rodriguez and Sachs (1999) introduce a different channel through which natural resources can appear to damage growth: depletion. Their model shows an underdeveloped country overshooting its steady state during a resource boom. After the initial rise in income, the growth rate turns negative, and the country converges to its steady state from above. Resource revenues consumed by the domestic economy will naturally decrease over time, tending to zero. In this way, after a country enjoys the resource boom, it negatively converges to its overshot steady state. Sachs and Warner's (2005) empirical evidence support this model by finding a negative growth rate associated with natural resource abundance only after an increase in initial wealth. One important implication is that the observed negative growth is simply the reversion of the positive growth occurring immediately after the boom. Therefore it is a depletion effect, rather than natural resources, that is responsible for the negative growth rates. Rodriguez and Sachs show that if an economy instead invests its windfall in foreign assets that generate a steady stream of revenue, a negative growth rate can be averted.

\footnotetext{
${ }^{5}$ The book suggests that non-renewable natural resource should be viewed as assets rather than production.

${ }^{6}$ This is chapter 2 of Escaping the Resource Curse, by Humphreys, Sachs, and Stiglitz.

${ }^{7}$ Ch. 2 of Neither Curse nor Destiny
} 
Another channel of particular relevance for natural resource abundant countries is the vulnerability to external shocks and the different productive linkages that an economy has. Hausmann, Rodríguez, and Wagner (2007) show that countries with lower export flexibility - which they measure using an indicator of the density of the product space developed by Hausmann and Klinger(2006) have a harder time recovering from crises caused by export collapses, as it is more difficult for them to move productive resources to a new sector. This is particularly relevant for resource abundant countries as many natural resources, such as oil, are found to occupy areas of low density in the product space.

Jaime Ros (2000) illustrates a contrary case of resources enriching a country when sufficient industrial linkages exists. In these cases, the spending of resource rents can actually have an anti-Dutch disease effect. Two pieces of evidence supporting this thesis are the fact that in countries where natural resources are scarce, one observes stunted industrial development in areas that thrive in resource rich countries, and the fact that Latin America's "primary export phase" was fueled by resource abundance. When proper returns to scale existed in complementary industrial sectors, resource booms fueled major economic expansions.

In the last decade, however, most of the blame for poor growth rates in resource dependent states has been put on institutional weaknesses. A number of these explanations actually emphasize institutional interactions: many have observed (Karl 1997, Lederman and Maloney 2007, Wright and Czelusta 2007) that natural resources have been huge economic boons for many countries while appearing not to have helped, or even possibly to have hurt, other countries, suggesting the existence of conditional factors which may be amplifying any effect of natural resources. One logical suspect is institutions.

Lane and Tornell (1999) note that under certain circumstances, point-source resources such as fuels and minerals intensify rent-seeking behavior. Rent-seeking, by nature, leads to perverse fiscal redistribution, inefficient capital projects, and corruption. Lane and Tornell identify two main exacerbating traits. The first is the absence of strong legal and political institutions. The second is the presence of multiple power groups, such as parasitic provincial governments, protection-seeking industrial centers and labor unions, and political patronage networks. These two situations create what Lane and Tornell call a "voracity effect," where a large resource windfall will generate an increase in fiscal redistribution that is more than proportionate, thereby 
reducing growth. Guerrilla uprisings in Colombia, Nicaragua, El Salvador, Guatemala, and Peru, as well as Native American riots in Ecuador, Bolivia, Mexico, and Brazil, are examples. Di John (2009) explains that these are all the result of rival political groups using non-market methods to capture resource rents, another manifestation of the voracity effect.

Karl (1997) examines the nature of petro-state institutions in detail. She finds parallel institutions among rent-centered states, whether they be Venezuela, Nigeria, Saudi-Arabia, or even $16^{\text {th }}$ century Spain. In almost all cases, the state is the direct recipient of the rent wealth, which diminishes the need for taxation. Without taxation, the nature of the social contract between the government and citizens is eroded, while the state can expand its own jurisdiction. The state's primary purpose becomes spending. Success for businesses, labor organizations, and the middle-class is redefined as the ability to gain or curry political influence.

A significant finding unique to Karl's analysis is that the major failed petro-states, Nigeria, Algeria, Iran, and Venezuela, all had one defining characteristic: they developed their institutions at the same time that petroleum was discovered and multi-national oil companies entered the picture. In many cases, the oil companies helped write the tax laws, and countries' institutions formed around patronage and oil politics. In almost all cases, the state was the direct recipient of the rent wealth. Maloney (2007) shows that this led to a lack of interest in developing other industries, as demonstrated even in gold and silver rich $16^{\text {th }}$ century Spain. What resulted in Spain's case similarly developed for these other petro-states: a type of "cultural Dutch Disease."

Further work by Sala-i-Martin and Subramanian (2003) shows a direct causal relationship between natural resources and weak institutions. They theorize that natural resources influence growth indirectly through institutions. This would account for the lack of significance for the natural resource variable found in many analyses. Regressing natural resources directly on institutions produced surprisingly strong results. Even when a dummy for oil is included, the impact on institutions is still significantly negative. In fact, they find that once institutions have been controlled for, oil actually has a beneficial effect on growth.

Wantchenkon (2000) empirically demonstrates a causal relationship between natural resources and authoritarianism, finding that natural resources negatively impact democracy. Wantchenkon postulates that authoritarianism arises due to one-party dominance combined with weak rule of 
law. This incites the opposition to use non-constitutional means to compete for political power. In response, the incumbent pre-empts this move by repressing or banning the opposition party. However, when the rule of law is strong and political power is less concentrated, and distribution of resource rents is properly monitored by an independent agency, the incumbent's advantage is largely mitigated. This can be seen in Norway's case. ${ }^{8}$ His empirical results show no impact on democracy from natural resources in countries where resource dependence is low (10\% or less). However, when resource dependence is high ( $90 \%$ or more), a one percentage point increase in resource dependence leads to democracy index dropping $2.15 \% .{ }^{9}$ Nevertheless, the literature has failed to uncover a significant effect of democracy on growth, so that this is unlikely to be a major channel of transmission.

There are some cases where countries with weak institutions have enjoyed strong growth. Haber, Razo, Maurer (2003) investigate one such case. From 1876 to 1911, Mexican dictator Porfirio Diaz employed a system of selective property rights that were quite effective. The scheme secured protection for the economic elites but not for the masses. In fact, this system survived the 18 years of bloody civil war following Díaz's demise, allowing for healthy growth despite the existence of a failed state. Haber et al argue that an oil exporting country's government need not secure credible commitments to everyone. As long as government can make credible commitments to the privileged elites and companies responsible for the majority of economic activity, it is not necessarily imperative for property rights and beneficial institutions to extend to the population as a whole. While securing rights for the entire population is often viewed as a prerequisite for full development, the authors show that substantial growth can be obtained simply by securing property rights for the major oil companies, which requires "neither rule of law nor a stable polity."

A number of policies have been suggested to help alleviate any negative effects associated with natural resources. van Wijnbergen (1984) shows that government investment in human capital and industries intense in learning-by-doing spillovers will adequately protect a non-resource sector from Dutch Disease effects. Karl (1997) argues that resource dollars must be isolated from the domestic economy by such means as investing internationally, accumulating foreign

\footnotetext{
${ }^{8}$ Haber and Menaldo (2009) reject Watchenkon's findings.

${ }^{9}$ This uses 1998 data.
} 
reserves, and paying off foreign debts. Wantchekon (2000) similarly recommends a "resource fund," modelled on Norway's stabilization fund, as a way to keep resource money from negatively impacting an economy. Collier and Bevan (1996) recommend distributing the revenue directly to the citizenry. Revenue would then be obtained through taxing the citizenry rather than directly through resource rents. This, the authors argue, ensures greater wealth distribution while making the government more accountable to its taxpayers. Martin (2007) ${ }^{10}$ states that policies moving away from concentration in primary resource exports should be taken only if there are clear market failures arising from the overconcentration and if feasible alternative policies are actually available. Assuming a country would not choose to ignore its natural resource wealth, four options remain for diversifying exports. These include: raising levels of physical and human capital; increasing the competitiveness of other industries; lowering barriers to trade, and reducing transportation and communication costs.

With more data available and more sophisticated econometric techniques, it has become easier to tease out the true causes of economic collapse. Lederman and Maloney (2008) examine and critique the previous literature. They criticize Sachs' and Warner's proxy for resource abundance: exports as a share of GDP. For countries such as Singapore, this proxy shows bloated natural resource endowments, as large quantities of resources move through their ports. Sachs and Warner recognize this, and for two countries they used a different proxy: net resource exports as a share of GDP. Lederman and Maloney question why this metric wasn't used for all countries in their sample instead of just for these two countries. To some degree, resources move through all countries and therefore are incorrectly counted toward the proxy.

Lederman and Maloney (2008) show that when either proxy is used for all countries, the negative effect of natural resources found by Sachs and Warner vanishes. Additionally, Sala-iMartin, Doppelhofer, and Miller (2004) find that the Sachs and Warner proxy lacks sufficient robustness to be considered as a core explanatory variable. ${ }^{11}$ Lederman and Maloney show that after controlling for fixed effects in a panel context, the negative effect of natural resources disappears. Finally, they find that adding an export concentration variable (the Herfindahl index)

\footnotetext{
${ }^{10}$ Ch. 11 of Neither Curse nor Destiny.

11 The variable "fraction GDP in mining" ranked as the $12^{\text {th }}$ most robust explanatory variable. (Lederman and Maloney 2008).
} 
also eliminates the resource curse. ${ }^{12}$ The general conclusion that Lederman and Maloney (2007, 2008) draw from their analysis is that natural resources are assets for development that necessitate appropriate policies and adequate human and physical capital. They argue that countries can properly employ natural resources to create sustainable economic growth and development through proper export diversification, human and physical capital investment, volatility and real exchange rate control.

\subsection{Latin America: a Regional Comparison}

Venezuela's case is arguably the best researched in Latin America, with numerous studies and extensive available data. Venezuela's experience with rent-rich resources began with strong growth but was followed by economic deterioration. Venezuela's economy performed strongly in the first half of the $20^{\text {th }}$ century, boasting the highest growth rate in Latin America. After 1980, however, the country's economy deteriorated, with its non-oil sector growing one fourth the amount of Indonesia's and one sixth that of Mexico's. Rodríguez and Hausmann (2009) show that Venezuela's non-oil economic activity is primarily confined to energy intensive industries, which exploit the same comparative advantage in oil, doing little to protect the economy from its overreliance on petroleum products. Rodríguez and Hausmann (2009) use the export flexibility measure of Hausmann and Klinger (2006) - which these authors term "open forests" to look for traits in Latin America's petro-states, specifically Venezuela. They observe that Venezuela has a strikingly low open forest level, even compared to its neighbors. In 1980, at the start of Venezuela's growth collapse, its open forest was $13.8 \%$ of the world average and $15.7 \%$ of the South American average. A comparison with Mexico's higher level might help to explain Mexico's partial resilience to falling oil prices in the 1980s.

Rodríguez and Hausmann point out that while Venezuela has a remarkably low open forest, this appears to be a common trait of oil-exporting countries. Even after controlling for income, fuelexporters - those countries that have fuel make up over $80 \%$ of total exports - have an average open forest that is $2.17 \log$ points lower than non-fuel exporters. This implies that those inputs necessary for oil production have little value for producing other high-value exports.

\footnotetext{
${ }^{12}$ Due to our econometric analysis being closely based on the work by Lederman and Maloney, further discussion of their variables and technique is in a later section.
} 
But Venezuela did not always do poorly with oil. Rodríguez and Gomolin (2009) describe Venezuela's turn-of-the-century consolidation of economic, military, and political power, arguing that this was key to the country's success in developing the institutions for properly utilizing future oil revenue. At the turn of the century, before the discovery of oil, Venezuelan dictator Cipriano Castro had modernized the army, centralizing command and suppressing dissent. An intricately woven web of political patronage backed this authority under Castro's successor, Juan Vicente Gómez, when incentives for political support were increased and expanded. Thus Venezuela receives oil under a consolidated and centralized state.

In stark contrast, Mexico failed to centralize and consolidate its national public finances in the early 20th century. The armed forces remained un-modernized as well. Total municipal revenues almost equalled federal revenues, which stood at 4\% of GDP. Wealthy municipalities had access to military resources and posed the first challenges to the central government in the early 20th century. With no set of centralized political and economic institutions in place, the influx of oil revenue following 1910 did not generate the growth spurt in Mexico that occurred in Venezuela.

Di John (2009) studies the Venezuelan case from a political economy perspective. . Venezuela has enjoyed large oil revenues since 1920. Di John divides this 85-year span into two periods, each with its own polity type. From 1920 to 1968, Venezuela is described as a consolidated state with a centralized political organization. According to DiJohn, this type of polity could handle a big-push Import Substitution Industrialization (ISI) development plan backed by resource rents, since patronage can be deployed through a one-party state backed by an organized military. After 1968, however, the polity turned into what Di John calls a consolidated state with a fragmented political organization. This type of polity can handle only small scale ISI, for the high level of coordination necessary for big push ISI is not possible with such political friction. Therefore, Di John concludes, Venezuela began its economic decline due to the incompatibility of its development strategy with its changing polity type after 1968.

At the turn of the twentieth century, Argentina and Scandinavia enjoyed similar levels of wealth as well as similar levels of natural resources. Maloney (2007) puts forward evidence that Argentina's weak performance throughout the twentieth century stemmed from poor national learning and innovation systems, hindrances to technological adoption, and backward incentive 
structures arising from the protectionist era of ISI. This description could probably be extended to Latin America as a whole. Scandinavian countries, on the other hand, successfully developed with primary commodities. They used their natural resources as catalysts for learning and technological innovation, as did countries like the United States and Australia. These countries combined an early emphasis on literacy and education with investments in positive spilloveryielding, dynamic firms. These same firms developed into the high-tech companies that lead their respective industries today. Even when Scandinavian countries had the same level of income as Latin America, their literacy rates were two times greater. By 1842, a mere decade after a mandatory school system was introduced; Sweden's literacy rate was nearly 100 percent. The mixture of advanced education, knowledge clusters, industry financed research, and open economies are what distinguished Scandinavia from Latin America. As a result, Sweden and Finland have become case studies for successful development through natural resources. (Blomström and Kokko, 2007).

Bravo-Ortega and de Gregorio (2007) further explain the growth of disparity between different regions of the world through the $20^{\text {th }}$ century. They look at kilometers of railway, primary enrolment, and literacy rates from 1870 to 1910 as signs of differing levels of physical and human capital. Latin America lagged in all three categories behind Europe, Canada, the United States, and Australia. Using the Sachs and Warner (1995) proxy for natural resources, they find that when the average level of education for a country reaches just three years, natural resources become positively correlated with growth.

Latin American countries have had widely varying experiences with natural resources. Chile's copper industry dominated the country's economy for over 150 years, but a price boom from 1965-177 did little for the Chilean economy. Instead, Chile's economic acceleration began in 1982 with currency devaluation, financial reform, pension reform, and privatization (Collier and Sater, 1996). In a similar vein, Caselli and Michaels (2009) perform an intra-country study of Brazil to show that resource-rich municipalities enjoyed little to no social benefit from their oil windfalls. Caselli and Michaels argue that this was primarily due to corruption and inefficient distribution. Aragón and Rud (2009), on the other hand, demonstrate a positive effect of natural resources on the local population. They find that Yanacocha, a Peruvian gold mine, improved local incomes and standards of living. They argued that these improvements were not the result 
of an increase in social spending. Instead, they said that the effects resulted from an increase in demand for local inputs.

The oil boom of the 1970s resulted in the greatest reworking of the international economic landscape since the gold rush of the America's in the $16^{\text {th }}$ century (Karl, 1997). The record influx of cash to petro-states led to oversized government ambition and public spending. Benefits of this spending included a massive expansion of public welfare, an increase in employment, and a rise in the standard of living. Middle-Eastern countries offered free healthcare, education, and extensive pensions. Latin American countries invested in job creation and subsidized housing and fuel. Petro-governments in both regions took advantage of their newly unrestricted capital immediately. They embarked on massive spending campaigns, primarily involving capitalintensive projects. Viewing their oil as an exhaustible commodity, the governments spent rapidly.

Issues emerged immediately. Bottlenecks in production and limited capacity in management and infrastructure led to delays, inefficiencies, and rising domestic prices. The appreciating currency and unprecedented levels of state spending produced Dutch Disease effects. Local industry deteriorated, making the state even more dependent on petroleum. State expenditures quickly outpaced the massive oil revenues even while income remained high. Foreign capital was easily accessible for the first time due to countries' rent-derived collateral, but this led to a huge debt overhang. When prices dropped, petro-states were broke and unable to repay their loans.

However, not all countries experienced the same difficulties with their natural resources: certain countries were able to employ natural resources to fuel unprecedented growth and development. Wright and Czelusta (2007) examine $19^{\text {th }}$ century United States and its success with natural resources. Based on resource-fueled development, the United States overtook the United Kingdom in GDP per worker hour by 1890 and led the world in productivity by 1913. In arguments parallel to those of Karl (1997) and Maloney (2007), Wright and Czelusta contrast the US with former Spanish colonies who lived passively off of their resource rents. The US developed an accommodating legal environment, undertook massive investments in infrastructure and knowledge, and promoted resource focused education. In doing so, the US was able to produce more metals more efficiently than many countries with far larger resource endowments. Australia and Botswana provide further examples of successful resource-based 
growth. Australia created a knowledge intensive mineral sector that produces billions of dollars in intellectual property alone. Acemoglu, Johnson, and Robinson (2003) showcase Botswana as one of sub-Saharan Africa's lone success cases, a feat accomplished by combining good institutions with a thriving diamond-mining sector.

In general, the literature suggests that natural resources can be an important part of the countries pain or prosperity. However, it would be wrong to unequivocally state that natural resources are the reason for a country's woes. Instead, what the case studies suggest is that weak institutions and poor policies make countries vulnerable to the pitfalls presented by natural resources. Natural resources can also be a blessing, and some countries have used natural resources to fuel unprecedented growth and development.

\section{Data and empirical methodology}

Our empirical strategy is similar to that of Lederman and Maloney (2008), extended in two directions. First, we analyze the effect of natural resource abundance not only on per capita GDP growth but also on human development. Second, our sample goes from 1970 to 2005, given the newly available dataset of human development developed by Gray and Purser (2009).

For measuring the natural resource wealth of countries, our primary explanatory variable, there are many possible proxies in the literature. None is perfectly suited to the purpose of estimating coefficients in human development equations. Most scholars measure natural resources as the share of one or more of primary product exports, including agricultural raw materials, food, fuel, ores and metals to GDP (e.g. Nunn, 2008; Sala-i-Martin et al., 2004 and Leamer, 1999). However, most of the measures are not necessarily measures of resource abundance, but rather measures of dependence on natural resources. We use Lederman and Maloney's measure of net exports, which applies the primary goods groups of Leamer (1999). Natural resource exports per worker is our indicators of resource abundance, to which we will refer as the direct effect of natural resources on human development. ${ }^{13}$ A key advantage of this strategy is that this proxy, unlike other proxies, is positively correlated with natural resource endowment per worker.

\footnotetext{
${ }^{13}$ Lederman and Maloney define net exports of natural resources as "exports minus imports of natural-resourcerelated goods, based on Leamer's commodity clusters." See appendix A for a full description of all variables.
} 
Additionally, it has the advantage of being a multi-commodity trade-based proxy, which allows for a larger coverage of countries.

However, as Lederman and Maloney recognize, there could be two flaws with this proxy, both related to consumption. First, income growth increases consumption, which could lead to a bias when estimating the relationship between net exports per labor and income. There is clear empirical evidence of this, demonstrated by a positive correlation of exports and income among net exporters. There is even greater bias when non-resource related sectors cause this increase in income, resulting in a negative correlation of growth and exports. Second, an increase in imports and decrease in exports of natural resources is associated with a rise in capital endowments. ${ }^{14}$ To help solve these problems, they use an additional covariate: imports of natural resources per worker, which will measure the indirect effect on natural resources on human development. While the coefficient of interest remains that of the export variable, the sum of the two coefficients (the sum of the direct and indirect effect) measures the total effect of natural resources on human development.

The following analysis centers on two types of regressions. Our baseline results are generated by running a typical OLS cross-country growth regression, which includes a convergence term, a proxy for the abundance of natural resources, a set of conditional variables, and regional dummies. While with the linear regression we can address the question "on average, are natural resources good for human development?" it cannot answer the other important question: "do natural resources influence human development differently for countries in Latin America?" For this purpose, we also add to the previous regressions a set of regional dummies interactions and to check for any differential effect of natural resources among regions, particularly among Latin American countries.

One issue that frequently arises with least squares estimations is the role of outliers, posing the question of how to treat some countries' values that differ substantially from other countries' observations. These deviations can tilt the regression line upwards or downwards, and consequentially, the results can be driven by them (see e.g., Rodríguez, 2007 and Easterly, 2005). We thus estimate all our regressions eliminating these outliers. In order to do this, we use

\footnotetext{
${ }^{14}$ This relationship is extracted from the Rybczynski Theorem.
} 
the dfbeta measure proposed by Besley, Kuh and Welsch (1980), an influence measure which identifiesthose observations with a significant impact on the results. ${ }^{15}$ The dfbeta for a predictor and for a particular observation is the difference between the regression coefficient calculated for all of the data and the regression coefficient calculated with the observation deleted, scaled by the standard error calculated with the observation deleted.

\section{Results}

Tables 2.a - 2.e show the results of our panel regressions with HDI and its subcomponents changes as the dependent variable and natural resource abundance as the key variables of interest. All tables include three specifications that contain a convergence variable in addition to the resource variables along with regional dummies. The second set of specifications, in column two, also contain terms of trade growth and. We also have another set of specifications, in column three, which contain the institutional variable.

\section{OLS (Main results)}

In addition to the reported coefficients, significance levels, standard errors, and test statistics, we also calculated standardized regression coefficients in order to examine the relative importance of each variable for determining the growth (changes) in HDI. These so-called beta-coefficients make the magnitude of each individual exogenous variable's impact comparable by being unitfree.

Our OLS results indicate that natural resource abundance has a positive effect on human development, since the coefficients for the net exporters of natural resources are positive and statistically significant for all specifications. In analyzing the total effect of natural resources (the sum of the coefficients of net exports and total imports), we found that its effect is positive for both net resource exporting and importing countries, with the effect being stronger for net exporters, as shown by about twice as large standardized (beta) coefficients. Furthermore the statistical significance is more robust for the net exporters, as the total effect of natural resources

\footnotetext{
${ }^{15}$ See also Cook and Weisberg (1982). We restrict our estimations to the cut-off value for the absolute value of DFBETAs being smaller than $2 / \operatorname{sqrt}(\mathrm{N})$, where $\mathrm{N}$ is the number of observations.
} 
in determining HDI is statistically significant across all three specifications. Such a consistent result across models was not found for net importers, for whom natural resources are significant only after the inclusion of terms of trade growth. It is important to note that the coefficient for the net imports of natural resources is not significant in any regression. Also, for net importers, the indirect effect of natural resources (measured by the total imports per worker, M/L) is stronger than the direct effect (measured by the absolute value of their net exports of natural resources, NX/L), while for exporters the inverse holds true, indicating that the impacts of natural resources are mostly relevant in those countries where they are abundant.

All three specifications include the initial HDI level of 1970 to test for convergence. The negative and statistically significant coefficients of the initial HDI values of 1970 indicate that there is indeed convergence in human development. In fact the convergence term exerts more impact on human development and all of its subcomponents than any other explanatory variable, as we can see by comparing the absolute value of the beta coefficient.

After convergence, net exports of natural resources is the second most important variable in explaining changes in HDI. An increase of the natural resources exported by net exporters by a factor equivalent to one standard deviation leads to a 0.34 to 0.38 standard deviations increase in the change in HDI, depending on the model. This boost in HDI changes is only about one-ninth that of an equivalent increases by net importers, which implies that the effect of direct resource endowments is important only for net exporters. The reverse applies for indirect effects of natural resources, where only net natural resource importers demonstrate a significant response that is more than twice as strong as the insignificant beta coefficient for net exporters.

The inclusion of the terms of trade growth and institutional variables did not change the joint significance or magnitude of the two natural resource variables for net exporters and net importers, as reflected by the $\mathrm{F}$ test for the sum of coefficients.

We now turn to discussing the effects of natural resources on the components of the HDI. Natural resource abundance measures played a significant and positive role in all literacy models. In fact, both net export and net import as composite measures of the natural resources played a positive and significant role in the determination of literacy. The two other non-income HDI composites, gross enrolment and life expectancy show positive and significant relationships 
only for some specifications. For life expectancy, the joint effect is positive and mostly significant. Gross Enrolment was negatively and significantly affected by the indirect effect of natural resource endowments for exporters, an effect that is captured in the aggregation of the sum of both exporting coefficients. Both direct and indirect resource variables were negative for almost all specifications for importers. Only in one specification did natural resource abundance show a positive association with gross enrolment on a $10 \%$ significance level, and all but one sum of coefficients for either net exporters or importers showed a negative sign.

Regarding the income HDI component, GDP per capita growth shows that natural resource abundance could be a blessing for growth. ${ }^{16}$ In comparing the GDP to the HDI results, we find that the latter is more conclusive in terms or the statistical significance of the direct effect of natural resource abundance. For both the HDI and GDP we find that resource abundance is more important for exporters than importers. However, in the case of GDP, the effect of natural resources through total imports (the indirect effect) is stronger than the direct effect (through net export of natural resources). The standardized coefficients further show that the direct effect of natural resources $(\mathrm{NX} / \mathrm{L})$ is important for HDI (by a factor of almost two), while the indirect effect (M/L) is more important for GDP/capita (by a factor of around nine times more).

The previous discussion is illustrated with the following figures (Figures 1 and 2), which show a less significant effect of natural resource abundance on GDP growth than on HDI, particularly on the non-income components.

\footnotetext{
${ }^{16}$ This result is similar to that reported by Lederman and Maloney (2008), with the difference that our sample goes from 1970 to 2005 .
} 
Figure 1

\section{Relationship between GDP Growth, HDI Changes and Natural Resources}
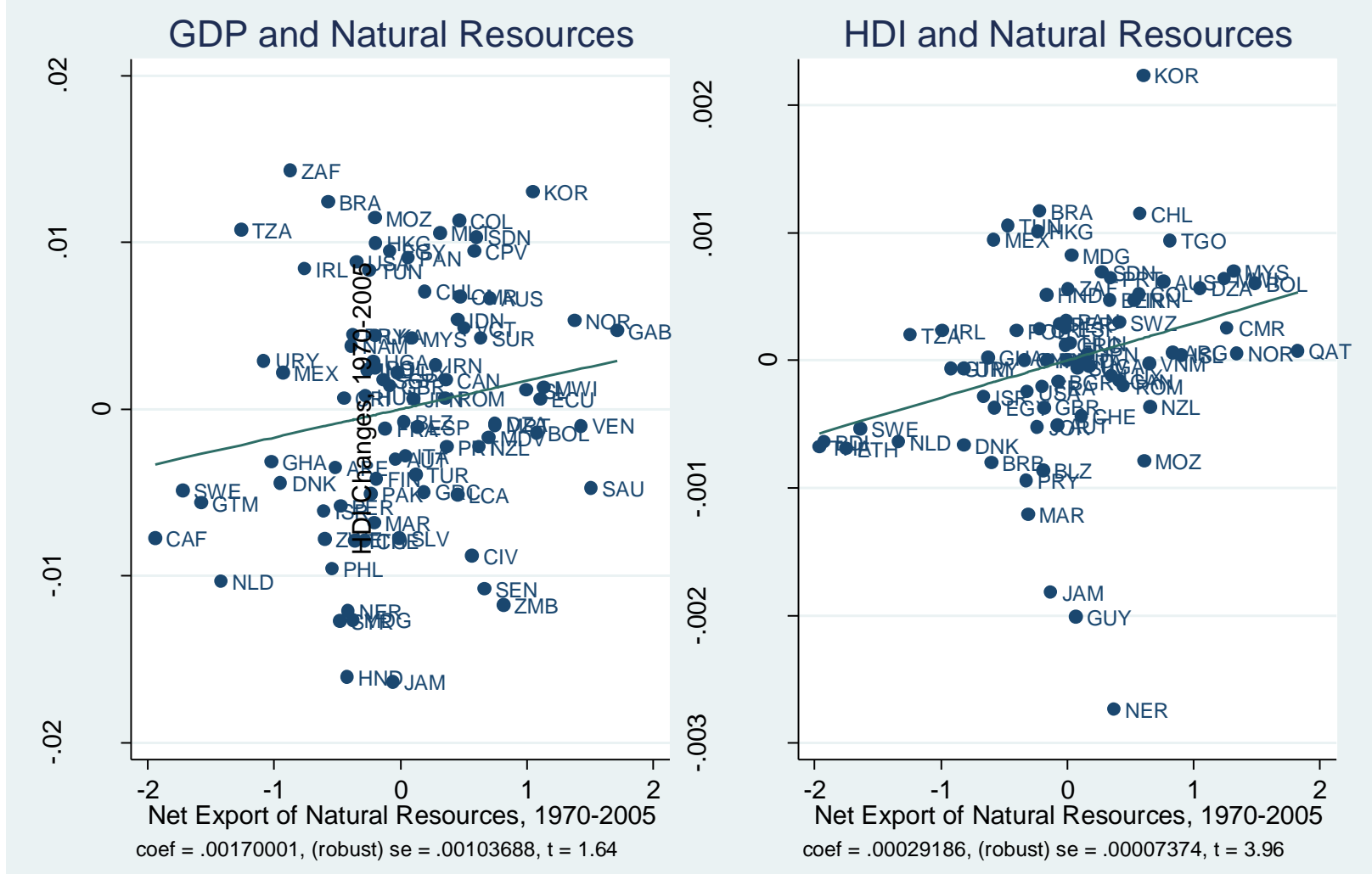

Source: Own calculations. 
Figure 2

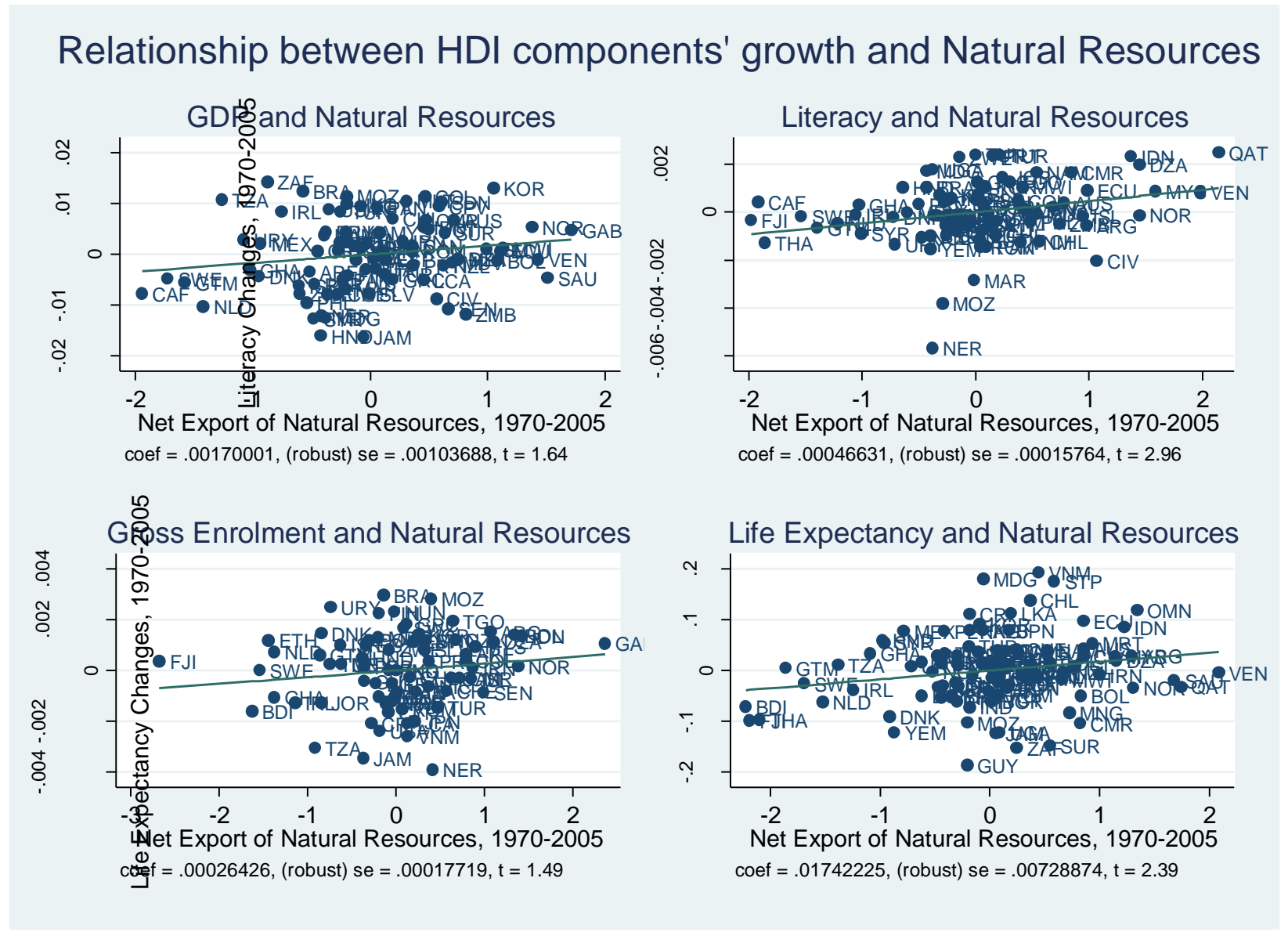

Source: Own calculations. 
Table 2.a: OLS results: Determinants of HDI change

\begin{tabular}{|c|c|c|c|c|c|c|}
\hline Explanatory variables: & coeff. & Beta & coeff. & Beta & coeff. & Beta \\
\hline \multirow[t]{2}{*}{ Net Natural Resource Exports (pos NX/L) } & $0.000292 * * *$ & 0.33981 & $0.000393 * * *$ & 0.35913 & $0.000394 * * *$ & 0.37969 \\
\hline & [7.37e-05] & & [7.59e-05] & & {$[7.63 e-05]$} & \\
\hline \multirow[t]{2}{*}{ Net Natural Resource Imports (neg NX/L) } & 0.00006 & 0.05156 & 0.00014 & 0.09365 & 0.00006 & 0.04509 \\
\hline & {$[0.000134]$} & & {$[0.000117]$} & & {$[0.000108]$} & \\
\hline \multirow[t]{2}{*}{ Total Imports of Net Natural Resource Exporters (pos M/L) } & 0.00006 & 0.05358 & $0.000225^{*}$ & 0.18589 & 0.00010 & 0.08394 \\
\hline & {$[0.000115]$} & & {$[0.000135]$} & & {$[0.000105]$} & \\
\hline \multirow[t]{2}{*}{ Total Imports of Net Natural Resource Importers (neg M/L) } & 0.00022 & 0.12004 & 0.00035 & 0.15518 & $0.000373^{* *}$ & 0.18974 \\
\hline & {$[0.000167]$} & & {$[0.000221]$} & & {$[0.000177]$} & \\
\hline \multirow[t]{2}{*}{ HDI in 1970} & $-0.0134 * * *$ & -1.71018 & $-0.0159 * * *$ & -1.78169 & $-0.0146 * * *$ & -1.78237 \\
\hline & {$[0.00236]$} & & [0.00149] & & {$[0.00161]$} & \\
\hline \multirow[t]{2}{*}{ Terms of Trade Growth } & & & -0.00071 & -0.00646 & $-0.0100 *$ & -0.09460 \\
\hline & & & {$[0.00735]$} & & [0.00593] & \\
\hline \multirow[t]{2}{*}{ Executive Constraint } & & & & & 0.00062 & 0.17232 \\
\hline & & & & & {$[0.000455]$} & \\
\hline \multicolumn{7}{|l|}{ Sum of coefficients: } \\
\hline $\operatorname{pos} N X / L+\operatorname{pos} M / L$ & 0.00035 & 0.39339 & 0.00062 & 0.54502 & 0.00049 & 0.4636242 \\
\hline$F$ test & 6.63000 & & 16.80000 & & 15.90000 & \\
\hline$p$ value & 0.01250 & & 0.00010 & & 0.00020 & \\
\hline neg NX/L + neg $M / L$ & 0.000287 & 0.17159 & 0.00049 & 0.24883 & 0.00043 & 0.2348335 \\
\hline$F$ test & 2.29000 & & 6.70000 & & 7.06000 & \\
\hline$p$ value & 0.13520 & & 0.01240 & & 0.01070 & \\
\hline Observations & 73 & & 66 & & 61 & \\
\hline R-squared & 0.79 & & 0.865 & & 0.888 & \\
\hline
\end{tabular}

Table 2.b: OLS results: Determinants of GDP/capita growth

\begin{tabular}{|c|c|c|c|c|c|c|}
\hline Explanatory variables: & coeff. & Beta & coeff. & Beta & coeff. & Beta \\
\hline Net Natural Resource Exports (pos NX/L) & $\begin{array}{l}0.00170 \\
{[0.00104]}\end{array}$ & 0.16956 & $\begin{array}{l}0.00198^{* *} \\
{[0.000959]}\end{array}$ & 0.18609 & $\begin{array}{l}0.00093 \\
{[0.00111]}\end{array}$ & 0.10190 \\
\hline Net Natural Resource Imports (neg NX/L) & $\begin{array}{l}0.00064 \\
{[0.00135]}\end{array}$ & 0.04772 & $\begin{array}{l}0.00036 \\
{[0.00112]}\end{array}$ & 0.02928 & $\begin{array}{l}0.00011 \\
{[0.00144]}\end{array}$ & 0.00989 \\
\hline Total Imports of Net Natural Resource Exporters (pos M/L) & $\begin{array}{l}0.00769 * * * \\
{[0.00138]}\end{array}$ & 0.66068 & $\begin{array}{l}0.00751^{* * *} \\
{[0.00139]}\end{array}$ & 0.63625 & $\begin{array}{l}0.00581^{* * *} \\
{[0.00192]}\end{array}$ & 0.58137 \\
\hline Total Imports of Net Natural Resource Importers (neg M/L) & $\begin{array}{l}0.00934^{* * *} \\
{[0.00158]}\end{array}$ & 0.53767 & $\begin{array}{l}0.0101^{* * *} \\
{[0.00164]}\end{array}$ & 0.60918 & $\begin{array}{l}0.00659^{* *} \\
{[0.00266]}\end{array}$ & 0.44100 \\
\hline In GDP/capita in 1970 & $\begin{array}{l}-0.0158^{* * *} \\
{[0.00214]}\end{array}$ & -1.01210 & $\begin{array}{l}-0.0136 * * * \\
{[0.00245]}\end{array}$ & -0.91855 & $\begin{array}{l}-0.0102^{* * *} \\
{[0.00280]}\end{array}$ & -0.78807 \\
\hline Terms of Trade Growth & & & $\begin{array}{l}-0.129 * * * \\
{[0.0479]}\end{array}$ & -0.16614 & $\begin{array}{l}-0.08490 \\
{[0.0541]}\end{array}$ & -0.13258 \\
\hline In Executive Constraint & & & & & $\begin{array}{l}0.00406 \\
{[0.00383]}\end{array}$ & 0.15532 \\
\hline \multicolumn{7}{|l|}{ Sum of coefficients: } \\
\hline $\begin{array}{l}\operatorname{pos} N X / L+\operatorname{pos} M / L \\
F \text { test }\end{array}$ & $\begin{array}{l}0.00939 \\
45.92000\end{array}$ & 0.83024 & $\begin{array}{l}0.00949 \\
39.75000\end{array}$ & 0.82234 & $\begin{array}{l}0.00674 \\
7.77000\end{array}$ & 0.68327 \\
\hline$p$ value & 0.00000 & & 0.00000 & & 0.00740 & \\
\hline $\begin{array}{l}\text { neg } N X / L+\text { neg } M / L \\
F \text { test } \\
p \text { value }\end{array}$ & $\begin{array}{l}0.009976 \\
50.68000\end{array}$ & 0.58538 & $\begin{array}{l}0.01046 \\
62.29000\end{array}$ & 0.63846 & $\begin{array}{l}0.00670 \\
5.68000\end{array}$ & 0.45089 \\
\hline Observations & 85 & & 78 & & 68 & \\
\hline R-squared & 0.78 & & 0.802 & & 0.753 & \\
\hline
\end{tabular}


Table 2.c: OLS results: Determinants of Change in Literacy Ratio

\begin{tabular}{|c|c|c|c|c|c|c|}
\hline Explanatory variables: & coeff. & Beta & coeff. & Beta & coeff. & Beta \\
\hline \multirow[t]{2}{*}{ Net Natural Resource Exports (pos NX/L) } & $0.000466 * * *$ & 0.17814 & $0.000521^{* * *}$ & 0.16870 & $0.000634 * * *$ & 0.20423 \\
\hline & [0.000158] & & [0.000179] & & {$[0.000198]$} & \\
\hline \multirow[t]{2}{*}{ Net Natural Resource Imports (neg NX/L) } & 0.00011 & 0.02773 & 0.00006 & 0.01604 & 0.00012 & 0.02780 \\
\hline & {$[0.000214]$} & & {$[0.000222]$} & & {$[0.000210]$} & \\
\hline \multirow[t]{2}{*}{ Total Imports of Net Natural Resource Exporters (pos M/L) } & 0.00021 & 0.06877 & $0.000438 * *$ & 0.13132 & $0.000705^{* * *}$ & 0.21182 \\
\hline & {$[0.000224]$} & & {$[0.000212]$} & & {$[0.000237]$} & \\
\hline \multirow[t]{2}{*}{ Total Imports of Net Natural Resource Importers (neg M/L) } & $0.00112^{* * *}$ & 0.22469 & $0.00128 * * *$ & 0.22706 & $0.00151 * * *$ & 0.25711 \\
\hline & [0.000282] & & [0.000354] & & [0.000394] & \\
\hline \multirow[t]{2}{*}{ Literacy in 1970} & $-0.0137^{* * *}$ & -0.94903 & $-0.0161 * * *$ & -1.02477 & $-0.0167^{* * *}$ & -1.03237 \\
\hline & {$[0.00156]$} & & {$[0.00132]$} & & {$[0.00136]$} & \\
\hline \multirow[t]{2}{*}{ Terms of Trade Growth } & & & 0.00351 & 0.01442 & -0.01330 & -0.05828 \\
\hline & & & [0.00984] & & {$[0.0108]$} & \\
\hline \multirow[t]{2}{*}{ Executive Constraint } & & & & & -0.00108 & -0.11603 \\
\hline & & & & & {$[0.000680]$} & \\
\hline \multicolumn{7}{|l|}{ Sum of coefficients: } \\
\hline $\operatorname{pos} N X / L+\operatorname{pos} M / L$ & 0.00068 & 0.24691 & 0.00096 & 0.30002 & 0.00134 & 0.41605 \\
\hline$F$ test & 6.53000 & & 10.40000 & & 14.43000 & \\
\hline$p$ value & 0.01270 & & 0.00200 & & 0.00040 & \\
\hline neg NX/L + neg $M / L$ & 0.00123 & 0.25243 & 0.00134 & 0.24311 & 0.00163 & 0.28492 \\
\hline$F$ test & 25.71000 & & 20.11000 & & 21.62000 & \\
\hline$p$ value & 0.00000 & & 0.00000 & & 0.00000 & \\
\hline Observations & 84 & & 80 & & 70 & \\
\hline R-squared & 0.892 & & 0.912 & & 0.93 & \\
\hline
\end{tabular}

Table 2.d: OLS results: Determinants of Gross Enrolment Ratio

\begin{tabular}{|c|c|c|c|c|c|c|}
\hline Explanatory variables: & coeff. & Beta & coeff. & Beta & coeff. & Beta \\
\hline \multirow[t]{2}{*}{ Net Natural Resource Exports (pos NX/L) } & 0.00026 & 0.18679 & 0.00012 & 0.07226 & $0.000320^{*}$ & 0.18069 \\
\hline & {$[0.000177]$} & & {$[0.000194]$} & & {$[0.000188]$} & \\
\hline \multirow[t]{2}{*}{ Net Natural Resource Imports (neg NX/L) } & -0.00007 & -0.02960 & 0.00000 & -0.00186 & -0.00004 & -0.01891 \\
\hline & {$[0.000310]$} & & {$[0.000336]$} & & {$[0.000277]$} & \\
\hline \multirow[t]{2}{*}{ Total Imports of Net Natural Resource Exporters (pos M/L) } & $-0.000618^{* *}$ & -0.35604 & $-0.000797 * *$ & -0.45089 & -0.00033 & -0.17626 \\
\hline & [0.000305] & & {$[0.000336]$} & & {$[0.000275]$} & \\
\hline \multirow[t]{2}{*}{ Total Imports of Net Natural Resource Importers (neg M/L) } & -0.00042 & -0.12466 & -0.00060 & -0.17468 & 0.00016 & 0.04365 \\
\hline & [0.000444] & & [0.000499] & & {$[0.000556]$} & \\
\hline \multirow[t]{2}{*}{ Gros Enrolment in 1970} & $-0.0136 * * *$ & -0.94458 & $-0.0146 * * *$ & -0.99961 & $-0.0175 * * *$ & -1.07918 \\
\hline & {$[0.00206]$} & & [0.00159] & & {$[0.00156]$} & \\
\hline \multirow[t]{2}{*}{ Terms of Trade Growth } & & & $-0.0376^{* * *}$ & -0.20804 & $-0.0375 * * *$ & -0.19903 \\
\hline & & & [0.0134] & & {$[0.0122]$} & \\
\hline \multirow[t]{2}{*}{ Executive Constraint } & & & & & $0.00222^{* * *}$ & 0.35130 \\
\hline & & & & & {$[0.000566]$} & \\
\hline \multicolumn{7}{|l|}{ Sum of coefficients: } \\
\hline $\operatorname{pos} N X / L+\operatorname{pos} M / L$ & -0.00035 & -0.16925 & -0.00068 & -0.37864 & -0.00001 & 0.00443 \\
\hline$F$ test & 1.69000 & & 4.93000 & & 0.00000 & \\
\hline$p$ value & 0.19810 & & 0.03070 & & 0.94950 & \\
\hline neg $N X / L+$ neg $M / L$ & -0.00049 & -0.15426 & -0.00061 & -0.17654 & 0.00012 & 0.02474 \\
\hline$F$ test & 1.51000 & & 2.33000 & & 0.08000 & \\
\hline$p$ value & 0.22460 & & 0.13310 & & 0.77420 & \\
\hline Observations & 73 & & 66 & & 65 & \\
\hline R-squared & 0.651 & & 0.728 & & 0.786 & \\
\hline
\end{tabular}


Table 2.e: OLS results: Determinants of Life Expectancy

\begin{tabular}{|c|c|c|c|c|c|c|}
\hline Explanatory variables: & coeff. & Beta & coeff. & Beta & coeff. & Beta \\
\hline \multirow[t]{2}{*}{ Net Natural Resource Exports (pos NX/L) } & $0.0174^{* *}$ & 0.19841 & 0.01100 & 0.09235 & 0.01380 & 0.11097 \\
\hline & {$[0.00729]$} & & [0.00977] & & [0.00993] & \\
\hline \multirow[t]{2}{*}{ Net Natural Resource Imports (neg NX/L) } & 0.00027 & 0.02433 & -0.00275 & -0.02185 & -0.00069 & -0.00532 \\
\hline & {$[0.00748]$} & & [0.00898] & & {$[0.00947]$} & \\
\hline \multirow[t]{2}{*}{ Total Imports of Net Natural Resource Exporters (pos M/L) } & 0.00356 & -0.00948 & 0.00987 & 0.07540 & $0.0266^{* *}$ & 0.19638 \\
\hline & {$[0.0114]$} & & {$[0.0134]$} & & [0.0119] & \\
\hline \multirow[t]{2}{*}{ Total Imports of Net Natural Resource Importers (neg M/L) } & 0.00127 & -0.03744 & 0.00874 & 0.05095 & $0.0289 *$ & 0.15890 \\
\hline & {$[0.00966]$} & & [0.0144] & & {$[0.0172]$} & \\
\hline \multirow[t]{2}{*}{ Life Expetancy in 1970} & $-0.0189 * * *$ & -1.05483 & $-0.0189 * * *$ & -1.20715 & $-0.0197 * * *$ & -1.23390 \\
\hline & {$[0.00164]$} & & {$[0.00181]$} & & {$[0.00176]$} & \\
\hline \multirow[t]{2}{*}{ Terms of Trade Growth } & & & 0.23800 & 0.02821 & -0.50100 & -0.05742 \\
\hline & & & [0.504] & & [0.510] & \\
\hline \multirow[t]{2}{*}{ Executive Constraint } & & & & & -0.03150 & -0.08682 \\
\hline & & & & & {$[0.0440]$} & \\
\hline \multicolumn{7}{|l|}{ Sum of coefficients: } \\
\hline $\operatorname{pos} N X / L+\operatorname{pos} M / L$ & 0.02096 & 0.18893 & 0.02087 & 0.16775 & 0.04040 & 0.30735 \\
\hline$F$ test & 3.98000 & & 2.12000 & & 8.28000 & \\
\hline$p$ value & 0.04910 & & 0.14960 & & 0.00540 & \\
\hline neg $N X / L+$ neg $M / L$ & 0.00154 & -0.01310 & 0.00599 & 0.02910 & 0.02821 & 0.15358 \\
\hline$F$ test & 0.02000 & & 0.18000 & & 3.48000 & \\
\hline$p$ value & 0.88160 & & 0.67490 & & 0.06660 & \\
\hline Observations & 102 & & 90 & & 79 & \\
\hline R-squared & 0.803 & & 0.788 & & 0.865 & \\
\hline
\end{tabular}

\section{OLS (Regional interactions results)}

Table 3 replicates our main results and similarly includes HDI and its subcomponents changes as the dependent variable and natural resource abundance as the key variables of interest, but includes a set of regional interaction effects for Latin America. Similar to our previous set of results, all tables include a convergence variable in addition to the resource variables along with regional dummies.

These new set of regressions confirm our main results that natural resource abundance has a positive effect on human development, since the coefficients for the net exporters of natural resources are positive and statistically significant for all specifications. Similarly, in analyzing the total effect of natural resources (the sum of the coefficients of net exports and total imports) on human development, we also found that its effect is positive for net resource exporting countries. However, the Latin America interaction effect shows that the impact of natural resources on human development is significantly smaller for this region compared with the rest of the natural resource abundant regions and countries. This result is shown in table 3 , where we can see that the Latin America interaction coefficients are of the opposite sign and mostly 
significant. This indicates that for Latin America the positive effect of natural resources is relatively small and in some cases the total coefficient for the region is not significantly different from zero.

Table 3: Latin America interaction results: Determinants of HDI change

\begin{tabular}{|c|c|c|c|c|c|}
\hline & HDI & GDP & Literacy & Gross Enrolment & Life Expectancy \\
\hline Explanatory variables: & coeff. & coeff. & coeff. & coeff. & coeff. \\
\hline \multirow[t]{2}{*}{ Net Natural Resource Exports (pos NX/L) } & $0.234^{* * *}$ & $0.256^{* * *}$ & $0.00102^{* * *}$ & $0.00370^{*}$ & $0.0379^{* * *}$ \\
\hline & {$[0.0214]$} & [0.0391] & {$[0.000290]$} & [0.00198] & [0.00512] \\
\hline \multirow[t]{2}{*}{ Net Natural Resource Imports (neg NX/L) } & 0.000187 & 0.00134 & -0.000139 & $-0.000849^{* * *}$ & 0.0135 \\
\hline & {$[0.000221]$} & {$[0.00153]$} & {$[0.000316]$} & {$[0.000296]$} & {$[0.0106]$} \\
\hline \multicolumn{6}{|l|}{ Total Imports of Net Natural Resource } \\
\hline \multirow[t]{2}{*}{ Exporters (pos M/L) } & $-0.199 * * *$ & $-0.218^{* * *}$ & 0.000709 & $-0.00218^{* * *}$ & -0.106 \\
\hline & [0.0182] & [0.0313] & {$[0.000728]$} & {$[0.000789]$} & [0.109] \\
\hline \multicolumn{6}{|l|}{ Total Imports of Net Natural Resource } \\
\hline \multirow[t]{2}{*}{ Importers (neg M/L) } & $6.20 \mathrm{E}-06$ & $0.00761^{* * *}$ & $0.00124^{* *}$ & -0.00022 & -0.0188 \\
\hline & {$[0.000249]$} & {$[0.00214]$} & {$[0.000574]$} & [0.000428] & [0.0137] \\
\hline \multirow[t]{2}{*}{ Value in 1970} & $-0.0141^{* * *}$ & $-0.0168^{* * *}$ & $-0.0128^{* * *}$ & $-0.0143^{* * *}$ & $-0.0185^{* * *}$ \\
\hline & {$[0.00275]$} & {$[0.00262]$} & [0.00195] & {$[0.00331]$} & {$[0.00176]$} \\
\hline \multirow{2}{*}{ Dummy Latin America and the Caribbean } & 0.000773 & $-0.0152^{* * *}$ & -0.000822 & -0.00186 & $0.300^{* * *}$ \\
\hline & {$[0.000609]$} & {$[0.00401]$} & {$[0.000736]$} & {$[0.00126]$} & {$[0.0494]$} \\
\hline \multicolumn{6}{|l|}{ Interaction Latin America and Net Natural } \\
\hline \multirow[t]{2}{*}{ Resources Exports } & $-0.234^{* * *}$ & $-0.253^{* * *}$ & $-0.000807^{*}$ & $-0.00419 *$ & $-0.0469 * * *$ \\
\hline & [0.0217] & [0.0395] & [0.000408] & [0.00218] & [0.0166] \\
\hline \multirow{2}{*}{$\begin{array}{l}\text { Interaction Latin America and Total Import } \\
\text { of Net Natural Resources Exporters }\end{array}$} & & & & & \\
\hline & $\begin{array}{l}0.199^{* * *} \\
{[0.0181]}\end{array}$ & $\begin{array}{l}0.223^{* * *} \\
{[0.0315]}\end{array}$ & $\begin{array}{c}-0.00118 \\
{[0.000843]}\end{array}$ & $\begin{array}{c}0.000821 \\
{[0.000994]}\end{array}$ & $\begin{array}{c}0.129 \\
{[0.110]}\end{array}$ \\
\hline Observations & 70 & 78 & 85 & 77 & 100 \\
\hline R-squared & 0.814 & 0.802 & 0.888 & 0.711 & 0.817 \\
\hline
\end{tabular}

\section{Conclusions}

This paper shows evidence against a natural resource curse on human development. We find evidence that changes of human development from 1970 to 2005, proxied by changes in the Human Development Index, are positively and significantly correlated with natural resource abundance. When we decompose the results for each HDI components, we find that natural resources could be positive for GDP growth but, most significantly, we find stronger evidence that natural resources are good for the non-income components of human development (especially literacy and life expectancy). These results contribute to a broader discussion of development by indicating that the positive effect of natural resource abundance is clearer for human development than for GDP growth, mainly through the education and health dimensions. 
We have also studied the effect of resource abundance on progress in human development in the Latin America region. Results from the Latin America interactions show that the positive impact of natural resources on that region is significantly smaller than in the rest of the world. Since the average results are still positive and significant for the rest of regions, this suggests the possible existence of institutional features in the region that interact with natural resources in a detrimental way. Nevertheless, even in Latin America's case there is no evidence that natural resources harm human development.

\section{References}

Acemoglu, Daron, Simon Johnson, and James Robinson. "The Colonial Origins of Comparative Development: An Empirical Investigation." American Economic Review 91.5 (2001): $1369-401$.

Belsley, David A., Edwin Kuh, and Roy E. Welsch. Regression Diagnostics Identifying Influential Data and Sources of Collinearity (Wiley Series in Probability and Statistics). New York: Wiley-Interscience, 2004.

Blomström, Magnus, and Ari Kokko. "From Natural Resources to High-Tech Production: The Evolution of Industrial Competitiveness in Sweden and Finland." Natural resources, neither curse nor destiny. Ed. Daniel Lederman and William F. Maloney. Palo Alto, CA: Stanford Economics and Finance, an imprint of Stanford UP, World Bank, 2007. Bravo-Ortega, Claudio, and José De Gregorio. "The Relative Richness of the Poor? Natural Resources, Human Capital, and Economic Growth." Natural resources, neither curse nor destiny. Ed. Daniel Lederman and William F. Maloney. Palo Alto, CA: Stanford Economics and Finance, an imprint of Stanford UP, World Bank, 2007.

Cook, R. D., and S. Weisberg. Residuals and Influence in Regression. London: Chapman and Hall, 1982.

Corden, W. M. "Booming Sector and Dutch Disease Economics: Survery and Consolidation." 
Oxford Economic Papers New Series 36.3 (1984): 359-80.

Cuddington, John T., Rodney Ludema, and Shamila A. Jayasuriya. "Prebisch-Singer Redux." Natural resources, neither curse nor destiny. Ed. Daniel Lederman and William F. Maloney. Palo Alto, CA: Stanford Economics and Finance, an imprint of Stanford UP, World Bank, 2007.

Di John, Jonathan. From Windfall to Curse?: Oil and Industrialization in Venezuela, 1920 to the Present. Modern Humanities Research, 2009.

Dunning, Thad. "Resource Dependence, Economic Performance, and Political Stability." The Journal of Conflict Resolution 49.4 (2005): 451-82.

Easterly, W. (1999), “Life during Growth”, Journal of Economic Growth, Vol. 4, No. 3, pp. 23976.

Easterly, William. "National Policies and Economic Growth: A Reappraisal." Handbook of Economic Growth, Volume 1A (Handbooks in Economics). Ed. Philippe Aghion and Steven N. Durlauf. Chapel Hill: North Holland, 2005.

Gray, G. and M. Purser. "Descriptive Statistics and Figures: Is It All Really About Income?"" HDRO, UNDP (2009).

Haber, Stephen, and Victor Menaldo. "Do Natural Resources Fuel Authoritarianism? A Reappraisal of the Resource Curse." Draft (2009).

Hausmann, Ricardo, and Francisco Rodríguez (2009), eds. Venezuela: Anatomy of a Collapse. Harvard University, Kennedy School of Government, Forthcoming.

Hausmann, Ricardo, Francisco Rodríguez and Rodrigo Wagner (2007) "Growth Collapses," in Carmen Reinhart, Andrés Velasco and Carlos Vegh, eds. Money, Crises, and Transition: Essays in Honor of Guillermo Calvo. Cambridge: MIT Press.

Hausmann, Ricardo, Jason Hwang and Dani Rodrik (2006) "What You Export Matters," 
forthcoming in Journal of Economic Growth.

Humphreys, Macartan, Jeffrey D. Sachs, and Josephy E. Stiglitz. Escaping the Resource Curse (Initiative for Policy Dialogue at Columbia: Challenges in Development and Globalization). New York: Columbia UP, 2007.

Karl, Terry Lynn. The Paradox of Plenty: Oil Booms and Petro-States. University of California, 1997.

Koenker, Roger, and Kevin F. Hallock. "Quantile Regression." Journal of Economic Perspectives 15.4 (2001): 143-56.

Leamer, Edward E., Hugo Maul, Sergio Rodriguez, and Peter K. Schott. "Does Natural Resource Abundance Increase Latin American Income Inequality?" Journal of Development Economics 59 (1999): 3-42.

Lederman, Daniel, and L. Colin Xu. "Comparative Advantage and Trade Intensity: Are Traditional Endowments Destiny?" Natural resources, neither curse nor destiny. Ed. Daniel Lederman and William F. Maloney. Palo Alto, CA: Stanford Economics and Finance, an imprint of Stanford UP, World Bank, 2007.

Lederman, Daniel, and William F. Maloney. "Neither Curse nor Destiny: Introduction to Natural Resources and Development." Natural resources, neither curse nor destiny. Ed. Daniel Lederman and William F. Maloney. Palo Alto, CA: Stanford Economics and Finance, an imprint of Stanford UP, World Bank, 2007.

Lederman, Daniel, and William F. Maloney. "Trade Structure and Growth." Natural resources, neither curse nor destiny. Ed. Daniel Lederman and William F. Maloney. Palo Alto, CA: Stanford Economics and Finance, an imprint of Stanford UP, World Bank, 2007.

Mahon, Jr, James E. "Was Latin America Too Rich to Prosper? Structural and Political Obstacles 
to Export-Led Industrial Growth." The Journal of Development Studies 28.2 (1992): 241-

63.

Maloney, William F. "Missed Opportunities: Innovation and Resource-Based Growth in Latin America." Natural resources, neither curse nor destiny. Ed. Daniel Lederman and William F. Maloney. Palo Alto, CA: Stanford Economics and Finance, an imprint of Stanford UP, World Bank, 2007.

Manzano, Ozmel, and Roberto Rigobón. "Resource Curse or Debt Overhang?" Natural resources, neither curse nor destiny. Ed. Daniel Lederman and William F. Maloney. Palo Alto, CA: Stanford Economics and Finance, an imprint of Stanford UP, World Bank, 2007.

Martin, Will. "Outgrowing Resource Dependence: Theory and Developments." Natural resources, neither curse nor destiny. Ed. Daniel Lederman and William F. Maloney. Palo Alto, CA: Stanford Economics and Finance, an imprint of Stanford UP, World Bank, 2007.

Nunn, Nathan. "The Long-Term Effects of Africa's Slave Trades." Quarterly Journal of Economics 123.1 (2008): 139-76.

Rodríguez, Francisco, and Adam J. Gomolin. "Anarchy, State, and Dystopia: Venezuelan Economic Institutions before the Advent of Oil." Bulletin of Latin American Reseaerch 28.1 (2009): 102-21.

Rodríguez, Francisco, and Jeffrey D. Sachs. "Why Do Resource-Abundant Economies Grow More Slowly?" Journal of Economic Growth 4 (1999): 277-303.

Rodríguez, Francisco. "Cleaning Up the Kitchen Sink: Growth Empirics When the World Is Not Simple." Working Paper (2007). 
Rodríguez, Francisco (2009) “What does the Human Development Index Really Measure?” New York Times Frekaonomics Blog, http://freakonomics.blogs.nytimes.com/2009/06/01/another-perspective-on-the-humandevelopment-indexl, accessed April 29,2010.

Ros, J. (2000). Development Theory \& The Economics of Growth. The University of Michigan Press.

Sachs, Jeffrey D., and Andrew M. Warner. "Economic Reform and the Process of Global integration." Brookings Papers on Economoic Activity (1995a): 1-95.

Sachs, Jeffrey D., and Andrew M. Warner. "Natural Resource Abundance and Economic Growth." National Bureau of Economic Research Working Paper.5398 (1995b).

Sala-i-Martin, Xavier, and Arvind Subramanian. "Addressing the Resource Curse: An Illustration from Nigeria." National Bureau of Economic Research Working Paper.9804 (2003).

Sala-i-Martin, Xavier, Gernot Doppelhofer, and Ronald I. Miller. "Determinants of Long-Term Growth: A bayesian Averaging of Classical Estimates (BACE) Approach." American Economic Review 94.4 (2004): 813-35.

Tornell, Aaron, and Philip R. Lane. "The Voracity Effect." American Economic Review 89.1 (1999): 22-46.

Van Wijnbergen, Sweder. "The 'Dutch Disease': A Disease After All?" The Economic Journal 94.373 (1984): 41-55.

Venables, Anthony. "Trade, Location, and Development: An Overview of Theory." Natural resources, neither curse nor destiny. Ed. Daniel Lederman and William F. Maloney. Palo Alto, CA: Stanford Economics and Finance, an imprint of Stanford UP, World Bank, 
2007.

Wantchekon, Leonard. "Why do Resource Dependent Countries Have Authoritarian Governments?" Yale University (1999).

Wright, Gavin, and Jesse Czelusta. "Resource-Based Growth Past and Present." Natural resources, neither curse nor destiny. Ed. Daniel Lederman and William F. Maloney. Palo Alto, CA: Stanford Economics and Finance, an imprint of Stanford UP, World Bank, 2007. 


\section{Appendix A: Data, Variable Definitions, and Sources}

Variable

Natural

Resources by

Labor Force

Growth of GDP

per capita,

1970-2005

Log GDP per

capita

Openness

Terms-of-trade

Growth

HDI

Literacy rate, adult
Definition

Net exports of natural resources, defined as

exports minus imports, divided by the labor

force. The labor force is defined as the

population between the ages of 15 and 64 .

Average annual growth of real GDP per

capita (constant prices: chain series).

Author's Calculations based

on Penn World Table

(Summers, Heston, and Aten, 2002)

Penn World Table (Summers, Heston, and Aten, 2002)

Sachs and Warner (1995a)

Real GDP per capita (constant prices: chain series) divided by total population.

Percentage of years with open economic

(1995a). policies as defined by Sachs and Warner

The Growth of external terms of trade is defined as the ratio of export to import price World Development

Indicators indices of goods and services.

A composite index measuring average

Gray and Purser (2009) achievement in three basic dimensions of Human Development Report human development - a long and healthy Office

life, access to knowledge, and a decent standard of living.

The proportion of the adult population aged

Gray and Purser (2009)

15 years and older that is literate.

Office 
Life Expectancy The number of years a newborn infant could at Birth expect to live if prevailing patters of agespecific mortality rates at the time of birth were to stay the same throughout the child's life.

Enrolment ratio, The number of students enrolled in primary, gross combined, secondary, and tertiary levels of education for primary, secondary, and tertiary education
Gray and Purser (2009)

Human Development Report Office

Gray and Purser (2009)

Human Development Report Office 